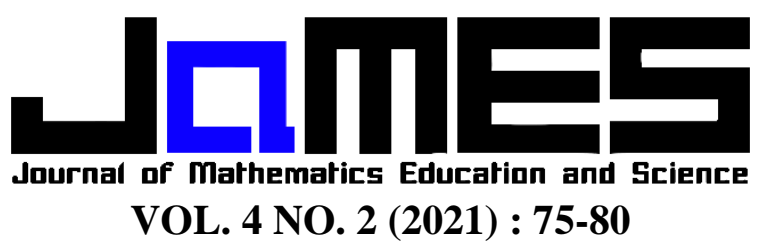

p-ISSN: 2621-1203 | https://doi.org/10.32665/james.v4i2.242

e-ISSN: 2621-1211

\title{
KLASTERISASI FAKTOR-FAKTOR KEMISKINAN DI PROVINSI JAWA BARAT MENGGUNAKAN K-MEDOIDS CLUSTERING
}

\author{
Pradini Nurul Safitri ${ }^{1}$, Rafika Aristawidya ${ }^{2}$, Shafa Bunga Faradilla ${ }^{3}$ \\ Corresponding author : S. B. Faradilla \\ Universitas Islam Indonesia, 18611049@ students.uii.ac.id ${ }^{1}$ \\ Universitas Islam Indonesia, 18611050@students.uii.ac.id ${ }^{2}$ \\ Universitas Islam Indonesia, 18611064@ students.uii.ac.id ${ }^{3}$ \\ Received : 17 September 2021, Revised : 23 Oktober 2021, Accepted : 25 Oktober 2021
}

(C) Mathematics Education Unugiri 2021

\begin{abstract}
Difficulty in meeting basic food and non-food need measured on the expenditure side is referred to as poverty. Thus, the purpose of this study is to find out the poverty group by district/city in West Java Province. This method used is the K-Medoids Clustering algorithm because K-Medoids can handle data that is very sensitive to outliers. The results of the study showed that three groups were obtained, with group one having as many as eight regions, group two having members as many as 15 regions, and group three having members as many as four regions.

Keywords: Poverty, K-Medoids Clustering, West Java Province

Abstrak

Kesulitan untuk memenuhi kebutuhan dasar makanan dan selain makanan diukur berdasarkan sisi pengeluaran disebut sebagai kemiskinan. Sehingga, tujuan penelitian ini yaitu mengetahui kelompok kemiskinan menurut kabupaten/kota di Provinsi Jawa Barat. Adapun metode yang digunakan yaitu algoritma K-Medoids Clustering, dikarenakan $K$-Medoids mampu mengatasi data yang sangat sensitif terhadap outlier. Hasil dari penelitian menunjukan bahwa diperoleh tiga kelompok, dengan kelompok satu memiliki anggota sebanyak delapan wilayah, kelompok dua memiliki anggota sebanyak yaitu 15 wilayah, dan kelompok tiga memiliki anggota sebanyak empat wilayah.
\end{abstract}

\section{Kata kunci: Kemiskinan, K-Medoids Clustering, Provinsi Jawa Barat}

\section{Pendahuluan}

Kemiskinan adalah masalah global yang sering dihadapi dan menjadi perhatian dunia. Kemudian, arti lain dari kemiskinan juga dapat dikatakan seperti masyarakat yang menganggur dan kurangnya lahan produktif sebagai asset pendapatan untuk masyarakat miskin atau masyarakat yang kurang mampu untuk memperoleh suatu kebutuhan paling dasar yaitu makan, air dan tempat tinggal [1].

Negara miskin sering kali dihadapkan pada masalah pertumbuhan dan pendapatan yang tidak merata, disisi lain banyak negara berkembang mengalami pertumbuhan ekonomi yang tinggi, namun kurang memberi manfaat bagi penduduk yang tergolong miskin. Indonesia sendiri tergolong negara berkembang, masalah kemiskinan selalu menjadi perhatian. Berbagai permasalahan yang muncul akan menyebabkan terjadinya pengangguran, kriminalitas, sulit untuk mendapatkan tempat tinggal yang baik, dan kemacetan. Dengan demikian, hal tersebut disebabkan karena jumlah penduduk yang semakin meningkat disuatu kabupaten/kota [1]. Provinsi Jawa Barat merupakan salah satu wilayah yang memiliki permasalahan kemiskinan yang 
meningkat, hal tersebut dapat dilihat berdasarkan grafik pada Gambar 1[2].

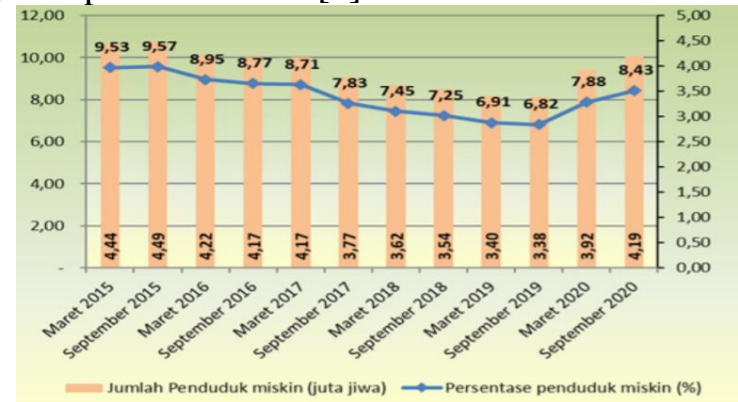

Gambar 1 Presentase Penduduk Miskin Jawa Barat tahun 2015-2017

Berdasarkan Gambar 1 periode Maret 2015 September 2019 tingkat kemiskinan di daerah Jawa Barat mengalami tren cenderung menurun. Sedangkan pada periode Maret - September 2020 mengalami kenaikan.

Penelitian ini menggunakan metode non hirarki yakni K-Medoids. Pusat klaster dari metode $K$-Medoids ditentukan dari perwakilan medoid atau objek. Sehingga, peneliti menggunakan metode $K$ Medoids untuk mengelompokkan kemiskinan di Provinsi Jawa Barat. Dengan demikian, peneliti ingin mengetahui kelompok kemiskinan berdasarkan faktor-faktor kemiskinan di Provinsi Jawa Barat menggunakan k-medoids clustering.

\section{Penelitian Terdahulu}

Berdasarkan faktor-faktor mengenai kemiskinan bahwa pada tahun 2017, yang meliputi rata-rata lama sekolah, presentase rumah tangga yang bekerja di pertanian, tingkat pengangguran terbuka, dan pengeluaran rumah tangga per kapita menggunakan metode average linkage hierarchical clustering menunjukan bahwa diperoleh dua kelompok kabupaten/kota di Pulau Jawa dengan tingkat kemiskinan rendah dan tinggi. Adapun kelompok tingkat kemiskinan rendah terdiri dari kota besar di Indonesia, sedangkan kelompok dengan tingkat kemiskinan tinggi meliputi wilayah pedesaan pada kabupaten/kota [1].

Adapun penelitian [3] menggunakan metode cluster average linkage meliputi angka melek huruf, tingkat pengangguran terbuka, angka partisipasi sekolah, dan pendidikan yang merupakan faktorfaktor kemiskinan pada tahun 2017 maka diperoleh sebanyak tiga kelompok dengan tingkat kemiskinan rendah, sedang, dan tinggi.
Mengacu pada website Open Knowledge Maps menunjukan bahwa belum dilakukan adanya penelitian terhadap faktor-faktor atau komponenkomponen kemiskinan di Provinsi Jawa Barat menggunakan K-Medoids Clustering. K-Medoids Clustering mirip dengan Algoritma K-Means [4], dimana K-Means sangat sensitif terhadap outlier sehingga mampu diatasi oleh K-Medoids [5]. Persamaan penelitian ini dengan beberapa penelitian sebelumnya yaitu serupa dalam melakukan pengelompokan berdasarkan faktor kemiskinan. Adapun faktor-faktor tersebut dalam penelitian ini meliputi jumlah penduduk miskin, tingkat pengangguran terbuka, rata-rata lama sekolah, dan produk domestik regional bruto. Sehingga, peneliti tertarik untuk melakukan pengelompokkan di Provinsi Jawa Barat berdasarkan faktor kemiskinan pada tahun 2020 di suatu kabupaten/kota.

Algoritma K-Medoids Clustering digunakan dalam penelitian, yang menunjukan bahwa masyarakat yang berasal dari wilayah Indonesia dengan ciri suhu badan diatas 36,9 derajat celcius dan disertai dengan batuk serta demam [6].

Penelitan [7] menggunakan algoritma $K$ Medoids Clustering menunjukan bahwa diperoleh tiga kelompok, dengan kelompok tunagrahita ringan berjumlah 5 siswa, kelompok tunagrahita sedang berjumlah 16 siswa dan kelompok tunagrahita berat berjumlah 6 siswa.

Adapun dalam penelitian [8] menggunakan $K$ Medoids Clustering yang bertujuan untuk mengetahui potensi daerah rawan gempa bumi, yaitu diperoleh tiga kelompok yang terbentuk. Kelompok pertama dicirikan dengan kekuatan gempa antara 3 SR hingga 3,4 SR, kelompok kedua dicirikan dengan kekuatan gempa pada daerah rawan gempa bumi antara 3,5 SR hingga 4,5 SR, dan kelompok ketiga dicirikan dengan kekuatan gempa pada aderah rawan gempa bumi yang berkisar antara 4,5 SR sampai dengan 5,7 SR.

\section{Landasan Teori}

\subsection{Kemiskinan}

Dalam [9] menurut World Bank, salah satu penyebab kemiskinan adalah pendapatan dan aset yang kurang untuk memenuhi kebutuhan dasar. Seseorang dengan keterbatasan lapangan pekerjaan berkaian dengan kemiskinan. Kemiskinan disebabkan oleh tingkat pendidikan dan kesehatan yang tidak layak, serta tidak memiliki pekerjaan disebut pengangguran. 
Menurut [10], kesulitan untuk memenuhi kebutuhan dasar makanan dan selain makanan yang diukur berdasarkan aspek pengeluaran disebut sebagai kemiskinan. BPS mengukur kemiskinan menggunakan Garis Kemiskinan (GK). GK yang dihasilkan hanya menggambarkan kondisi kemiskinan penduduk makro yang dapat digunakan untuk menggambarkan situasi kemiskinan di suatu daerah.

\subsection{Multikolinieritas}

Multikolinieritas yaitu dimana terjadi korelasi yang kuat antar variabel sehingga variabel-variabel yang digunakan harus terhindar dari multikolinearitas. Multikolinearitas bisa dideteksi dengan salah satu cara yaitu menghitung nilai tolerance/VIF. Nilai VIF $<0,1$ atau nilai VIF $>10$ maka terjadi multikolinearitas antar variabel [11].

\subsection{K-Medoids Clustering}

K-Medoids merupakan metode partisi clustering untuk mengelompokkan kumpulan $n$ objek ke dalam $k$ klaster. $K$-Medoids menggunakan medoid (objek) dengan menggunakan perwakilan pusat klaster untuk tiap-tiap klaster. Setiap objek yang berdekatan dengan pusat klaster akan dikumpulkan untuk membentuk sebuah klaster yang baru. K-Medoids mempunyai keunggulan dalam mengatasi kekurangan pada $K$ Means yang sensitif pada outlier. Meskipun dilakukan pengacakan terhadap data, hasil pengelompokan pada $K$-Medoids tetap sama [5]. Berikut tahapan-tahapan dari algoritma $K$-Medoids. 1. Memilih acak objek sebanyak $k$ dari $n$ objek yang ada sebagai representatif (medoids) banyaknya klaster yang ingin dibentuk.

2. Menghitung distance setiap objek nonmedoid terhadap setiap medoid dan menempatkan setiap objek ke klaster terdekat dengan medoid-nya. Hitung distance setiap objek terhadap masingmasing medoids dapat dihitung dengan jarak Euclidean seperti berikut.

$$
\left(x_{i j}, O_{i m}\right)=\sqrt{\begin{array}{r}
\left(x_{i 1}-O_{m 1}\right)^{2}+\left(x_{i 2}-O_{m 2}\right)^{2}+\cdots+ \\
\left(x_{i q}-O_{m q}\right)^{2}
\end{array}}
$$

(Error! No text of specified style in document..1) dengan $d\left(x_{i j}, O_{m j}\right)$ adalah distance dari data ke- $i$ pada variabel ke- $j$ terhadap medoids ke$m$ dimana $m=1,2, \ldots, k$ serta $j=1,2, \ldots, q$.

3. Seleksi dengan acak pada objek tiap klaster selaku calon medoid baru

4. Kalkulasikan suatu distance pada masingmasing objek yang terdapat di tiap-tiap klaster melalui kandidat medoid baru

5. Kalkulasikan jumlah seluruh simpangan atau $\mathrm{S}$ dengan mengkalkulasikan nilai jumlah distance baru dengan jumlah distance lama. Apabila $S<0$, lakukanlah penukaran suatu objek pada data klaster agar terbentuk serangkaian k objek baru untuk medoid

6. Berikutnya lakukan pengulangan pada tahap ketiga sampai pada tahap kelima, sampai medoid tidak lagi mengalami perubahan, sehingga diperoleh klaster dan juga anggota masing-masing klaster.

\section{Metode Penelitian}

Menggunakan data sekunder yang diambil pada situs BPS Jawa Barat. Populasinya adalah seluruh kabupaten/kota di Provinsi Jawa Barat, sedangkan masing-masing kabupaten/kota di Provinsi Jawa Barat merupakan sampel. Metode yang digunakan yaitu K-Medoids Clustering.

Variabel-variabel penelitian yang digunakan antara lain empat variabel yakni Kemiskinan (X1), Tingkat Pengangguran Terbuka (X2), Rata-rata Lama Sekolah (X3), dan Produk Domsetik Regional Bruto (PDRB) (X4).

Adapun langkah-langkah analisis dalam penelitian ini adalah sebagai berikut.

a. Mendeskripsikan setiap variabel indikator untuk mengetahui karakteristiknya.

b. Melakukan pengumpulan data dan input data

c. Melakukan uji multikolinieritas

d. Melakukan penentuan jumlah klaster

e. Jika jumlah klaster sudah ditentukan, maka dilanjutkan dengan melakukan analisis $K$ Medoids Clustering

f. Menarik kesimpulan

\section{Pembahasan}

\subsection{Statistika Deskriptif}

Statistika deskriptif berfungsi untuk memberikan sebuah gambaran umum mengenai variabel yang digunakan yaitu Kemiskinan (X1), 
Tingkat Pengangguran Terbuka (X2), Rata-rata Lama Sekolah (X3), dan Produk Domsetik Regional Bruto (PDRB) (X4). Analisis deskriptif yang diperoleh dapat dilihat pada Tabel 1 berikut ini.

Tabel 1. Analisis Deskriptif

\begin{tabular}{ccccc}
\hline Hasil & \multicolumn{4}{c}{ Variabel } \\
\cline { 2 - 5 } & X1 (\%) & X2 (\%) & X3(Thn) & X4 (Rp) \\
\hline Min. & 2.450 & 5.080 & 6.30 & 13866961 \\
\hline Mean & 8.425 & 9.980 & 8.54 & 28323931 \\
\hline Max. & 12.970 & 14.290 & 11.28 & 76947023 \\
\hline
\end{tabular}

Berdasarkan Tabel 1. Gambaran umum pada variabel Kemiskinan, Pengangguran, RLS, dan PDRB berdasarkan kabupaten/kota di Provinsi Jawa Barat tertinggi yaitu variabel Kemiskinan berada pada wilayah kota Tasikmalaya sebesar 12.970, variabel Pengangguran di Bogor sebesar 14.290, variabel RLS di kota Depok sebesar 11.280, dan variabel PDRB sebesar 76947023 di kota Sukabumi. Kemudian untuk nilai terendah pada variabel Kemiskinan berada di wilayah kota Depok sebesar 2.450, variabel Pengangguran di Pangandaran sebesar 5.080, variabel RLS di Indramayu sebesar 6.300, dan variabel PDRB sebesar 13866961 di Garut. Sedangkan untuk rata-rata Kemiskinan adalah 8.425, untuk Pengangguran sebesar 9.980, RLS sebesar 8.541, dan PDRB sebesar 28323931.

\subsection{Uji Data Outlier}

Data outlier adalah data yang sering disebut sebagai data pencilan. Penelitian ini dilakukan uji data outlier menggunakan grafik boxplot. Berikut tampilan output-nya.

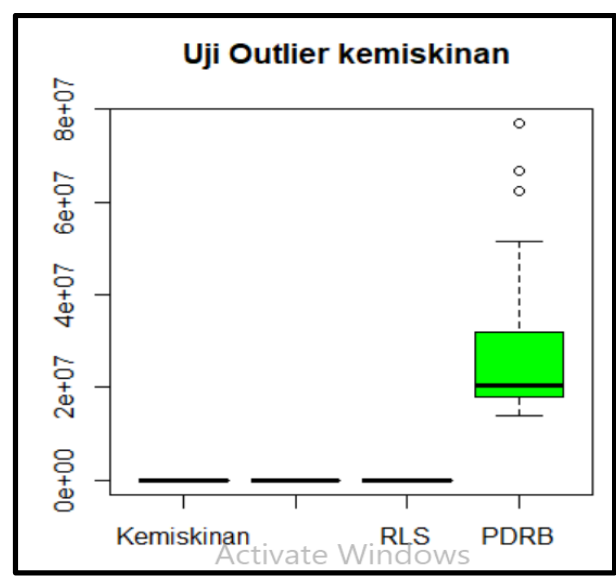

Gambar 2 Uji Deteksi Outlier

Dari Gambar 2 didapatkan hasil bahwa terdapat adanya outlier pada salah satu variabel. Oleh karena itu, untuk data dengan outlier disarankan menggunakan analisis klaster non hirarki yaitu $k$ medoids clustering. Selanjutnya dilakukan standarisasi data seperti Gambar 2.

\subsection{Uji Multikolinieritas}

Pengecekan multikolinearitas merupakan asumsi dalam analisis kluster non hirarki yaitu diharapkan no multikolinearitas atau sebaiknya tidak ada korelasi antar variabel. Pada pengecekan no multikolinearitas ini menggunakan nilai VIF atau nilai dari matriks korelasi dari semua variabel. Tabel 2 berikut merupakan hasil yang diperoleh dari pengujian multikolinieritas.

Tabel 2. Uji Multikolinieritas

\begin{tabular}{cc}
\hline Variabel & VIF \\
\hline $\mathrm{X} 1$ & 2.098643 \\
\hline $\mathrm{X} 2$ & 1.179057 \\
\hline $\mathrm{X} 3$ & 2.211367 \\
\hline $\mathrm{X} 4$ & 1.099583 \\
\hline
\end{tabular}

Pada Tabel 2 terlihat bahwa nilai VIF yang diberikan antar variabel Kemiskinan, Pengangguran, RLS, dan PDRB memiliki nilai VIF kurang dari $10(V I F<10)$. Dilakukan uji hipotesis berikut.

\section{$\mathrm{H}_{0}$ : No multikolinearitas}

$\mathrm{H}_{1}$ : Multikolinearitas

Diperoleh bahwa nilai VIF antar semua variabel kurang dari 10 (VIF<10). Daerah kritis merupakan daerah penolakan, dimana $\mathrm{H}_{0}$ ditolak jika VIF $>10$. Karena semua nilai VIF $<10$, maka keputusan yang diperoleh ialah gagal tolak $\mathrm{H}_{0}$. Maka disimpulkan bahwa pada tingkat kepercayaan $95 \%$, diperoleh bahwa data tersebut tidak terdapat korelasi antar semua variabelnya.

\subsection{Analisis Clustering K-Medoids}

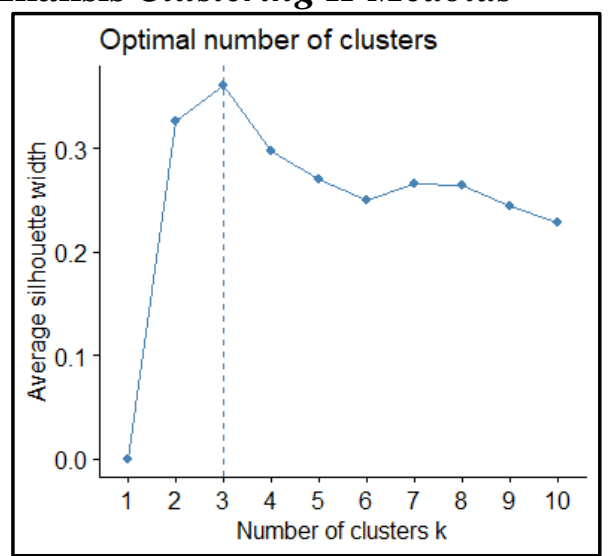

http://journal.unugiri.ac.id/index.php/JaMES 


\section{Gambar 3 Penentuan Klaster Optimal}

Metode silhoutte pada Gambar 3 menunjukan hasil penentuan jumlah $k$ klaster kemiskinan di provinsi Jawa Barat, dengan pendekatan nilai ratarata yang digunakan untuk memprediksi kualitas dari klaster yang terbentuk. Dengan demikian, apabila nilai rata-ratanya semakin tinggi maka jumlah klaster yang terbentuk akan semakin bagus dan optimal, dimana jumlah $k$ klaster optimum ketika $k=3$.

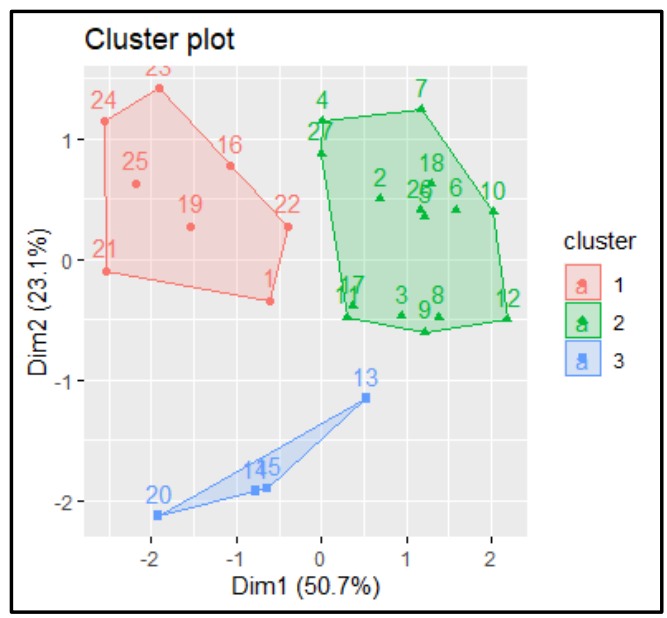

Gambar 4 Plot Hasil Klaster

Tabel 3. Hasil Pengelompokkan Klaster

\begin{tabular}{|c|c|c|c|}
\hline Klaster & $\begin{array}{c}\text { Pusat } \\
\text { Klaster }\end{array}$ & Anggota & $\begin{array}{c}\text { Jumlah } \\
\text { Anggota }\end{array}$ \\
\hline 1 & Bogor & $\begin{array}{c}\text { Bogor, Bekasi, } \\
\text { Kota Bogor, Kota } \\
\text { Bandung, Kota } \\
\text { Bandung, Kota } \\
\text { Cirebon, Kota } \\
\text { Bekasi, Kota } \\
\text { Depok, Kota } \\
\text { Cimahi }\end{array}$ & 8 \\
\hline 2 & Garut & $\begin{array}{l}\text { Sukabumi, Cianjur, } \\
\text { Bandung, Garut, } \\
\text { Tasikmalaya, } \\
\text { Ciamis, Kuningan, } \\
\text { Cirebon, } \\
\text { Majalengka, } \\
\text { Sumedang, } \\
\text { Indramayu, } \\
\text { Bandung Barat, } \\
\text { Pangandaran, Kota } \\
\text { Tasikmalaya, Kota } \\
\text { Banjar. }\end{array}$ & 15 \\
\hline
\end{tabular}

\begin{tabular}{clcc}
\hline Klaster & $\begin{array}{c}\text { Pusat } \\
\text { Klaster }\end{array}$ & Anggota & $\begin{array}{c}\text { Jumlah } \\
\text { Anggota }\end{array}$ \\
\hline \multirow{3}{*}{3} & $\begin{array}{l}\text { Purwa- } \\
\text { karta }\end{array}$ & $\begin{array}{c}\text { Pubang, } \\
\text { Karwakarta, } \\
\text { Sukabumi. Kota }\end{array}$ \\
\hline
\end{tabular}

Setelah jumlah $k$ telah ditetapkan, langkah selanjutnya yaitu melakukan proses klaster. Klasterisasi yang dilakukan bertujuan untuk mengelompokkan kabupaten/kota dengan mengelompokkan menjadi 3 kelompok (Tinggi, Sedang, dan Rendah). Berikut tampilan plot visualisasi $K$-Medoids Clustering yang diperoleh.

Pada Gambar 4 diperoleh 3 klaster kemiskinan dengan masing-masing klaster memiliki ciri khas warna yang berbeda-beda. Adapun warna merah menunjukan klaster 1 yang beranggotakan 8 kota, warna hijau menunjukan klaster 2 yang beranggotakan 15 kota dan warna biru menunjukan klaster 3 yang beranggotakan 4 kota. Untuk mempermudah dalam membacanya, berikut pemaparan tabel pengelompokan di wilayah Jawa Barat.

Pada Tabel 3 merupakan hasil pengelompokan faktor kemiskinan menjadi 3 kelompok yang memiliki jumlah anggota berbeda-beda pada setiap klaster. Kelompok 1 memiliki anggota sebanyak 8 wilayah, kelompok 2 memiliki anggota sebanyak yaitu 15 wilayah, dan kelompok 3 memiliki anggota sebanyak 4 wilayah.

\subsection{Profilisasi}

Setelah mengetahui jumlah dan anggota klaster, selanjutnya melakukan profilisasi untuk mengetahui karakterisik dari setiap kelompok. Dalam melakukan profilisasi ini digunakan hasil rata-rata variabel pada setiap klister

Tabel 4. Hasil Profilisasi

\begin{tabular}{ccccc}
\hline Klaster & $\mathbf{X 1}$ & $\mathbf{X 2}$ & $\mathbf{X 3}$ & $\mathbf{X 4}$ \\
1 & 5.58 & 11.81 & 10.22 & 26828650 \\
\hline 2 & 9.95 & 8.71 & 7.74 & 19837542 \\
\hline 3 & 8.35 & 11.06 & 8.13 & 63138455 \\
\hline
\end{tabular}

Berdasarkan Tabel 4, maka dapat dilakukan interpretasi sebagai berikut.

a. Klaster 1 merupakan kelompok kabupaten/kota dengan ciri jumlah Pengangguran dan RLS yang tinggi, Kemiskinan yang rendah, dan PDRB yang sedang.

b. Klaster 2 merupakan kelompok kabupaten/kota dengan ciri jumlah Kemiskinan yang tinggi, 
jumlah Pengangguran, RLS, dan PDRB yang rendah.

c. Klaster 3 merupakan kelompok kabupaten/kota dengan ciri jumlah Kemiskinan, Penganguran dan RLS yang sedang, serta jumlah PDRB yang tinggi.

\section{Penutup}

Berdasarkan hasil penelitian yang diuraikan dapat ditarik kesimpulan bahwa Gambaran umum berdasarkan hasil analisis deskriptif yaitu Kota Tasikmalaya merupakan daerah yang memiliki jumlah Kemiskinan terbesar, dan Bogor merupakan wilayah yang memiliki jumlah Pengangguran tersebesar. Sedangkan kota Depok merupakan wilayah yang memiliki jumlah RLS terbanyak, dan kota Sukabumi merupakan wilayah yang memiliki jumlah PDRB terbanyak.

Pengelompokan dengan menggunakan metode $K$-medoids clustering diperoleh hasil klister 1 sebanyak 8 anggota. Klaster 2 sebanyak 15 anggota. Sedangkan klaster 3 sebanyak 4 anggota.

Berdasarkan karakteristik dari klaster 1, dengan jumlah Pengangguran tinggi dan Kemiskinan rendah, serta RLS tinggi dan PDRB sedang sehingga peneliti menamakannya sebagai wilayah dengan variabel kemiskinan yang cukup baik. Klaster 2 dengan jumlah Kemiskinan tinggi dan Pengangguran yang rendah, serta RLS dan PDRB yang rendah sehingga peneliti menamakannya sebagai wilayah dengan variabel kemiskinan yang kurang baik. Klaster 3 dengan jumlah Pengangguran dan Kemiskinan sedang, serta RLS sedang dan PDRB tinggi sehingga peneliti menamakannya sebagai wilayah dengan variabel kemiskinan yang cukup baik.

\section{Referensi}

[1] A. W. Disty Wahyuli, Handrizal Handrizal, Iin Parlina, Agus Perdana Windarto, Dedi Suhendro, "Mengelompokan Garis Kemiskinan Menurut Provinsi Menggunakan Algoritma K-Medoids," $J$. Ris. Sist. Inf. dan Tek. Inform., vol. 1, pp. 452-461, 2019, [Online]. Available: https://tunasbangsa.ac.id/seminar/index.php/
senaris/article/view/51\%0A.

Badan Pusat Statistik Jawa Barat, Perkembangan Tingkat Kemiskinan Provinsi Jawa Barat. Bandung: BPS Provinsi Jawa Barat, 2020.

[3] Q. Nafisah and N. E. Chandra, "Analisis Cluster Average Linkage Berdasarkan Faktor-Faktor Kemiskinan di Provinsi Jawa Timur," Zeta - Math J., vol. 3, no. 2, pp. 3136, Nov. 2017, doi: 10.31102/zeta.2017.3.2.31-36.

[4] W. Setiyawati, Implementasi Algoritma Partitioning Around Medoids (PAM) untuk Pengelompokan Sekolah Menengah Atas di DIY berdasarkan Nilai Daya Serat Ujian Nasional. Yogyakarta: (Skripsi) Jurusan Teknik Informatika Universitas Sanata Dharma, 2017.

[5] P. Arora, Deepali, and S. Varshney, "Analysis of K-Means and K-Medoids Algorithm For Big Data," Procedia Comput. Sci., vol. 78, no. December 2015, pp. 507512, 2016, doi: 10.1016/j.procs.2016.02.095.

[6] S. Sindi, W. R. O. Ningse, I. A. Sihombing, F. Ilmi R.H.Zer, and D. Hartama, "Analisis Algoritma K-Medoids Clustering Dalam Pengelompokan Penyebaran Covid-19 Di Indonesia," Jti (Jurnal Teknol. Informasi), vol. 4, no. 1, pp. 166-173, 2020.

[7] R. R. Husin Sariangsah*, Wanayumini, "Penentuan Kelas Menggunakan Algoritma $\mathrm{K}$ Medoids Untuk Clustering Siswa Tunagrahita," J. Media ..., vol. 5, pp. 83-89, 2021, doi: 10.30865/mib.v5i1.2547.

[8] D. Kurmiati, M. Z. Fauzi, Ripangi, A. Falegas, and Indria, "Clustering of Earthquake Prone Areas in Indonesia Using K-Medoids Algorithm," MALCOM Indones. J. Mach. Learn. Comput. Sci., vol. 1, no. 1, pp. 45-57, 2021.

[9] D. V. Ferezagia, "Analisis Tingkat Kemiskinan di Indonesia," J. Sos. Hum. Terap., vol. 1, no. 1, pp. 1-6, Jul. 2018, doi: 10.7454/jsht.v1i1.6.

[10] Badan Pusat Statistik, "Kemiskinan dan Ketimpangan," 2020. https://www.bps.go.id/subject/23/kemiskina n-dan-ketimpangan.html\#subjekViewTab1. I. Ghozali, Aplikasi Analisis Multivariat Edisi 4 dengan Program SPSS BP Unversitas Diponegoro. Semarang: 
BPUniversitas Diponegoro, 2007. 